\title{
Mångfald och sekularitet i religionskunskapsundervisning ${ }^{1}$
}

\author{
Av KARIN K Flensner, Lektor i Utbildningsvetenskap vid Högskolan Väst, Sverige. \\ Epost:karin.flensner@hv.se
}

I syftestexten för det svenska religionskunskapsämnet anges att undervisningen i religionskunskap ska ge eleverna «möjlighet att utveckla en beredskap att förstå och leva i ett samhälle präglat av mångfald [samt att eleverna] ska ges möjlighet att reflektera över och analysera människors värderingar och trosföreställningar och därigenom utveckla respekt och förståelse för olika sätt att tänka och leva» (Skolverket 2011). Samtidigt visar ett flertal studier att klassrumspraktiken och talet om religion i svenska skolmiljöer är starkt präglade av en sekularistisk diskurs om religion där religiösa livsåskådningar artikuleras som tillhörande en förgången tid, vara svårförenliga med ett rationellt, modernt och vetenskapligt förhållningssätt och att troende människor uppfattas som irrationella, lurade eller psykiskt sjuka (Berglund, 2017; Carlsson \& Thalén, 2015; Eddebo \& Magnusson, 2020; Flensner 2015; 2017; 2018; Holmqvist Lidh, 2016; Osbeck \& Lied, 2011; SKR, 2020; Vikdahl, 2018; von Brömssen, 2009, 2012; 2016). Många gånger är det andra elever som uttrycker denna typ av åsikter i undervisningen, men även lärare bidrar till att denna diskurs blir hegemonisk i klassrummet. Detta sekularistiska förhållningssätt uppfattats många gånger som en neutral position av de som uttrycker den, vilket får implikationer för hur man förhåller sig till olika aspekter av mångfald. I den här texten ska jag resonera kring relationen mellan sekularitet och mångfald och diskutera några möjliga implikationer för ickekonfessionell undervisning om religion. Jag kommer att utgå från resultat från empiriska studier av religionskunskapsundervisning. ${ }^{2}$

Trots att Sverige måste beskrivas som ett mångreligiöst land, väcker religion i det offentliga rummet starka känslor. Debatter om religionens roll i offentligheten, individuella rättigheter och religionsfrihetens gränser tenderar med jämna

1 Föreliggande artikel är en lätt bearbetad version av kapitlet Religionskunskapsämnet i fokus - sekularitet och mångfald, tidigare publicerad i O Franck, E. Hall \& B. Liljefors Persson (red) (2019) Religionskunskapsämnet $i$ fokus - utmaningar och möjligheter. Jubileumsbok. Föreningen Lärare i Religionskunskap. Årgång 50. Malmö: PCG. Publiceras med tillstånd från Föreningen Lärare i Religionskunskap.

2 Studierna som artikelns resonemang utgår från genomfördes dels inom ramen för mitt avhandlingsarbete (K. Flensner, 2015) dels inom ramen för forskningsprojektet Global conflicts with local consequences - learning and arguing about Middle Eastern conflicts in Swedish classrooms finansierat av Vetenskapsrådet (Diarienummer 2016-03605). Publikationer baserade på empiri från projektet: K. Flensner \& Von der Lippe, 2019; K. Flensner, Larsson, \& Säljö, 2019; K. Flensner, 2018a; 2019; 2020. 
mellanrum att bli laddade och polariserade. För att ge exempel på några av de frågor som är högt upp på den politiska agendan när detta skrivs: förbjuda manlig omskärelse, förbjuda konfessionella friskolor, förbjuda bön på arbetstid, förbud mot böneutrop och slöjförbud i grundskolan och andra kommunala verksamheter. Frågor om religion i det offentliga rummet tycks vara en känslig fråga $i$ dagens Sverige och mängden förslag som innehåller olika förbud relaterat till religion och trosutövning indikerar att många vill begränsa religionens synlighet i det offentliga rummet. Samtidigt, eller kanske just därför, menar jag att skolan och särskilt $i$ undervisning $i$ religionskunskap har en viktig uppgift $i$ att manövrera dessa perspektiv och hjälpa barn och unga att möta människor med olika erfarenheter, uppfattningar och identiteter och därmed bidra till ett mer nyanserat samtalsklimat.

Först beskrivs kort några perspektiv på sekularisering och religionskunskapsämnets utveckling i Sverige och därefter beskrivs hur detta kan ta sig uttryck i klassrumspraktiken. Sedan presenteras några perspektiv på mångfald och avslutningsvis diskuteras relationen mellan mångfald och sekularitet kopplat till religionskunskapsundervisning.

\section{SEKULARISERING}

Att Sverige beskrivs som världens mest sekulariserade land är ett omdöme som många svenskar uppskattar. Sekulariseringen associeras med modernitet, rationalitet, frihet, tolerans och individualism och i många fall länkas dessa värden till det som uppfattas som svenskt (Thurfjell, 2015).

Mycket av det sociologiska tänkandet om religion är präglad av en deterministisk och linjär syn på utveckling och det kausala sambandet mellan modernitet och sekularisering (se t.ex. Weber 2003 [1958]; Durkheim 1976 [1912]; Berger 1967; Luckman 1967). De förutspådde (utifrån olika utgångspunkter) religionernas framtida försvinnande och modernitet och urbanisering blev liktydigt med sekularisering. Taylor (2007) betonar sekularisering som just mångfald och valmöjligheter av livsåskådningar. Tidigare var en religiös livsåskådning i princip det enda alternativet - nu är en religiös livsåskådning en av oändligt många valmöjligheter och variationen inom och mellan olika religiösa och ickereligiösa förhållningsätt till tillvaron synliggörs på ett annat sätt i dagens mediesamhälle. Andra har tagit fasta på sekularisering som den process där religionens betydelse minskar på samhällelig, institutionell och individuell nivå (se t.ex. Casanova, 2003; Dobbelaire, 2009).

Sekularisering kan således användas som ett deskriptivt begrepp som söker beskriva religionens förändrade roll och funktion i samhällen. Men mycket av sekulariseringsteorierna från 1900-talet utgick från föreställningen om religionernas nära förestående försvinnande vilket många också menade var en 
önskvärd utveckling. I detta fall är det inte längre en deskriptiv utan en normativ hållning som kan beskrivas som sekularistisk. Sekularism förstås i den här artikeln som ett normativt begrepp som förespråkar både en sekulär stat och en ett sekulärt samhälle samt att religion och religiösa uttryck begränsas till den privata sfären. ${ }^{3}$

Religionernas utdöende som ett flertal av de tidiga religionssociologerna förutspådde visade sig empiriskt felaktig och nu används ofta begrepp som postsekularitet eller «religionens nya synlighet» för att uppmärksamma och beskriva religiös förändring i samhället. Postsekularism används också för att markera utvecklingen av många parallella tolkningar, som kan omfatta en religiös/andlig dimension eller inte - det är upp till individen att bestämma. Begreppet används även ibland normativt i bemärkelsen ett ömsesidigt erkännande mellan religiösa och icke-religiösa individer vilket som en förutsättning för att hantera skillnader och mångfald i ett pluralistiskt samhälle (Carlsson \& Thalén, 2015). Oavsett om man ansluter sig till en normativ sekularistisk ståndpunkt eller inte behöver vi fundera över hur ickekonfessionell religionskunskapsundervisning ska utformas i ett sekulärt men samtidigt mångreligiöst samhälle med en stor mångfald av religiösa och ickereligiösa identiteter och positioner.

\section{RELIGIONSKUNSKAPSÄMNET}

Det svenska religionskunskapsämnet har förändrats från konfessionell undervisning i kristendom till ickekonfessionell undervisning om religiösa och ickereligiösa livsåskådningar och etik. Religionskunskapsämnet har en intressant historia som är starkt präglad av samhällsutvecklingen och olika sociala, kulturella och politiska förändringar. Den allmänna folkskolan infördes 1842 efter mycket debatt. Liberaler lyfte fram betydelsen av en välutbildad befolkning i den begynnande industrialismen, medan konservativa debattörer såg stora risker med att sprida bildning i de breda folklagren. Kompromissen blev att kristendomen fick en central plats och kyrkoherden blev ordförande i skolstyrelsen. Det är intressant att notera att kristendomen får en så tydlig roll i den nya folkskolan samtidigt som 1800-talet innebär en ökad diversifiering i form av ett flertal parallella sociala förändringsprocesser till exempel i form av industrialisering, urbanisering, migration, demokratisering, frikyrkorörelsens växande utbredning och arbetarrörelsens etablering som en politisk kraft. Knappt hundra år senare, 1919, revideras kristendomsämnet efter kritik dels från frikyrkorörelsen som var kritiska till att ämnet i princip var förberedelse för konfirmationen i svenska kyrkan, och från arbetarrörelsen som var kritiska till den konfessionella karaktären på ämnet överhuvudtaget. Båda dessa grupper övervägde att starta egna skolor. Almén (2000) menar att eftersom den religiösa enheten inte längre existerade i samhället valde myndigheterna att tona ner de konfessionella dragen

3 För en diskussion om distinktionen mellan det normativa begreppet sekularism och det mer deskriptiva begreppet sekularisering se t.ex. Scharffs (2011). 
i ämnet för att så många som möjligt skulle kunna acceptera det och därigenom bibehålla skolan som en sammanhållande faktor i samhället. I spåren av 40- och 50-talets kulturdebatter infördes 1962 ett objektivitetskrav i den då nyinrättade 9-åriga grundskolans kristendomsämne. Där slogs det fast att undervisningen skulle vara objektiv och inte söka påverka eleverna att omfatta någon specifik livsåskådning. 1965 på gymnasiet och 1969 i grundskolan bytte ämnet namn till religionskunskap. Religionskunskapsämnets utveckling är således starkt påverkad av sekulariseringsprocesser och de förhållningssätt till religion som dominerat i samhället och jag menar att utformningen av ämnet sannolikt även bidragit till sekulariseringen (jmf. Willaime, 2007).

Idag är det svenska religionskunskapsämnet ett obligatoriskt ämne i både grundskola och gymnasieskola. Det är ett ickekonfessionellt ämne som ska behandla samtliga världsreligioner, centrala ickereligiösa livsåskådningar samt etik. Ämnet har normativa mål relaterat till samhällelig mångfald. I syftestexten för ämnet religionskunskap på gymnasiet anges att:

"Undervisningen ska ta sin utgångspunkt i en samhällssyn som präglas av öppenhet $i$ fråga om livsstilar, livshållningar och människors olikheter samt ge eleverna möjlighet att utveckla en beredskap att förstå och leva $i$ ett samhälle präglat av mångfald. [...]

De ska ges möjlighet att reflektera över och analysera människors värderingar och trosföreställningar och därigenom utveckla respekt och förståelse för olika sätt att tänka och leva» (Skolverket, 2011).

\section{SEKULARISERING I RELIGIONSKUNSKAPSKLASSRUMMET}

Hur tar sig sekulariseringen uttryck i klassrumspraktiken i dagens Sverige? I mitt avhandlingsarbete fann jag att talet i klassrummet när religionskunskap stod på schemat dominerades av en sekularistisk diskurs (K Flensner 2015). När jag påbörjade mitt avhandlingsarbete handlade mina frågor inte om sekularisering utan om vilka diskurser om religion som dominerar klassrumspraktiken. Jag genomförde klassrumsobservationer under 125 lektioner på yrkesprogram och studieförberedande program på tre gymnasieskolor som hade olika lokalisering (nära en större stad, en medelstor stad och landsbygd) men med en ungefärlig genomsnittlig elevsammansättning på skolnivå i form av utländsk och socioekonomisk bakgrund jämfört med befolkningen i övrigt. ${ }^{4}$ Min ambition var att undersöka hur man talade om religion på några «typiska» svenska gymnasieskolor. Jag återkommer nedan till varför denna ambition visade sig problematisk och till utmaningar med att fånga det typiska i dagens samhälle, men här vill jag först beskriva några framträdande drag i den sekularistiska diskurs som jag fann ofta dominerade talet om religion i klassrummet. För att det inte ska uppstå några missförstånd vill jag understryka att det i samtliga klassrum pågår en mängd

4 För utförligare resonemang om urval och metod se K Flensner (2015) 
processer. I avhandlingen (K Flensner 2015) beskriver jag hur en sekularistisk diskurs dominerar under de observerade lektionerna, men jag identifierar också andra sätt att tala som utmanar detta sätt att tala. Här ska jag emellertid fokusera på just den sekularistiska diskursen.

Det som var slående när jag började analysera de inspelade lektionerna var att lärare och elever talade om religion som något som andra hade, medan «vi», «vi i Sverige» och «vi i väst» beskrevs som sekulariserade, ickereligiösa eller möjligtvis privatreligiösa. Detta trots att det i samtliga klassrum satt elever som i samtal beskrev sig som troende inom olika religiösa traditioner. Att artikulera en ickereligiös eller ateistisk position (både bland lärare och elever) var oerhört mycket vanligare än att i klassrummet uttrycka en religiös position. Under de här 125 lektionerna förekom det bara en gång att en elev resonerade utifrån sin position som troende kristen. Det var något vanligare att elever med muslimsk bakgrund inkluderade detta som en del av sina resonemang i klassrummet. En tolkning av detta är att $i$ ett sekulariserat samhälle är religion en privatsak och skolan och klassrummet del av en offentlig miljö. Lösning i klassrummet blir då att tala om troende människor som «dom», «troende» «kristna» och «muslimer» som några andra, även i de fall då lärare och elever i andra sammanhang t.ex. i intervjuer beskrivit sig som troende. Den icke-religiösa eller ateistiska positionen uppfattades som neutral i förhållande till religion och genererade större legitimitet, medan en religiös utgångspunkt uppfattades som partisk.

Det var också vanligt att associera religion med en förgången tid eller mindre utvecklade samhällen, som möjligt vis fyllt en funktion tidigare under historien men nu, tack vare upplysning och vetenskap, spelat ut sin roll. Ickereligiositet konstruerades således som en modern och rationell position och religiositet som motsatsen. Centralt var också individualism som framstod som ett överordnat värde i samtliga klassrum. Att välja sitt liv, att välja vad jag tror på artikulerades som oerhört viktigt av eleverna. Att vara del av olika kollektiv, till exempel religiösa grupperingar eller traditioner, uppfattades som svårförenligt med individualism. Grunden till detta är att då religiositet i hög utsträckning associerades med att underkasta sig (mer eller mindre irrationella och märkliga) regler för hur folk ska klä sig, när och vad de ska äta och när och hur högtider ska firas. Det var inte ovanligt att undervisning fokuserade på just denna typ av «regler» för just kläder, mat och högtider. Att det finns en oändlig variation av förhållningssätt till den här typen av regler kom sällan i förgrunden, inte heller att det $\mathrm{i}$ alla kulturer och grupper, religiösa såväl som ickereligiösa finns olika förväntningar och traditioner som individer förhåller sig till. Individualism och rätt att själv välja sitt liv blev också synligt i diskussioner om barn som växte upp i troende familjer. Flera eleverna tyckte att barnen då «tvingades» in i en tradition som de själva inte valde. När läraren försökte påvisa att alla barn, oavsett om föräldrarna 
är troende eller inte, växer upp i sociala sammanhang och tar över mycket av föräldrarnas intressen och värderingar, menade eleverna att religion är en «värre» form av påverkan. Det är intressant att notera att religiösa symboler och praktiker verkade tillmätas större påverkanskraft och något som människor, framförallt barn, behövde skyddas från för att inte «påverkas» av.

\section{«Precis så!»och «Så är det inte»}

Sammanfattningsvis associerades ickereligiösa positioner med individualism, självständighet, kritiskt tänkande, neutralitet, modernitet och tolerans och religiösa positioner med det motsatta. Detta medförde att troende elever många gånger var tysta i klassrummet. I denna bemärkelse bidrog undervisningen till att troende personer konstruerades som «de andra». Denna «andrafiering» [jmf engelskans «othering»] av troende elever, är även väl belagt i forskning (se t.ex. Holmqvist Lidh, 2016; Moulin, 2011). Att sekularistiska diskurser påverkar hur lärare och elever talar om religion i klassrummet är föga förvånande - klassrummet är en spegel av det omgivande samhället och företeelser och uppfattningar som existerar i det omgivande samhället kommer att prägla klassrumspraktiken. Lärare kan visserligen välja att belysa och problematisera uppfattningar som dominerar i samhället, men behöver ändå förhålla sig till dem. Och när det gäller vissa dominerande uppfattningar är de ibland så självklara för oss att vi inte ser dem - det är så att säga svårt att urskilja «vattnet vi själva simmar i». Jag menar att det har funnits en omedvetenhet om hur sekularistiska diskurser om religion kan ta sig uttryck både i samhället och i religionskunskapsundervisningen, vilket i sin tur försvårar en mångfacetterad förståelse av religion och religiositet, men detta börjar möjligtvis förändras.

Jag har huvudsakligen fått två reaktioner på avhandlingen såsom den framställts i olika sammanhang. En del berättar om att avhandlingen beskriver något som de själva erfarit. Avhandlingen tycks framställa sätt att tala om tro och religion som många, inte minst personer som beskriver sig som kristna i olika traditioner, känner igen i svensk religionskunskapsundervisning. Dessa personer beskriver upplevelser av att tillhöra en religiös minoritet i relation till en sekulär majoritet. En motsatt reaktion, främst från lärare, har varit att «så är det inte alls i mitt klassrum». Och så är det givetvis. I beskrivningen ovan sammanställs hur det sekularistiska tar sig uttryck i 24 klassrum, och där beskrivs inte de diskurser som utmanar detta sätt att tala. Inget klassrum dominerades således uteslutande av en sekularistisk diskurs, i skolans värld är det alltid på många sätt samtidigt. Så det kan mycket väl vara så att andra diskurser är mer framträdande i olika klassrum. En anledning till detta kan vara sättet att organisera undervisning och introducera olika perspektiv (se t.ex. K. Flensner, 2018b) men det som många lärare lyfter fram i dessa samtal är elevernas bakgrunder och elevsammansätt- 
ningen i klassrummen. Hur påverkas religionsundervisningen av mångfald i form av olika bakgrunder, erfarenheter och livsåskådningar?

\section{RELIGIONSKUNSKAPSUNDERVISNING OCH MÅNGFALD}

Som framgick ovan fanns det en koppling mellan det sekulära och det som uppfattades som svenskt. I Sverige är «vi» upplysta, moderna, toleranta och i de flesta fall ickereligiösa. När den sekularistiska diskursen var i spel och man talade om religion och att vara troende i allmänhet, var detta relativt svårförenligt med svenskhet. Om klassrumsdiskussioner däremot behandlade olika religioner framträdde intressanta skillnader mellan hur olika religioner framställdes. Samma person som fastslagit att Sverige är världens mest sekulariserade land kunde samma lektion också säga att Sverige är ett kristet land. I diskussionerna gjordes detta ofta i kontrast till islam. Den kristendom som konstruerades i detta sammanhang handlade mindre om tro och mer om historia och traditioner och konstruerades i relation till islam: «vi» är ju inte muslimer och «vi firar liksom inte ramadan». Den kristendom som konstruerades var framförallt liberal och tolerant - «svensk kristendom» var inte konservativ och fundamentalistisk. En annan premiss som framkom under klassrumsobservationerna var att vi lever i en värld där det existerar många parallella uppfattningar och alla har rätt att tro vad de vill. Denna toleranta inställning artikulerades som en principiell hållning - när det kom till konkreta frågor var toleransen inte lika stor. Men religiositet förknippades $i$ hög utsträckning med intolerans, delvis med hänvisning till religioners förmodade exklusiva sanningsanspråk medan ickereligiösa positioner associerades med motsatsen - tolerans och öppenhet. På detta sätt kopplades kulturella föreställningar om svenskhet och sekularism samman vilket hänger samman med förhållningssätt till olika aspekter av mångfald.

Men vad menar vi med mångfald? Mångfald av vad? Är det en jämförelse med bilden av enhetssamhället då Sverige var en nation med ett folk, en tro, en kung ett språk? Den enheten är knappast en empirisk beskrivning av hur samhället såg ut mellan 1500-1800 utan mer ett ideal och en propagandabild. Det har alltid levt människor med olika språk och kulturella identiteter inom Sveriges gränser. Men samma förändringsprocesser som kan antas ha bidragit till sekularisering - såsom urbanisering, demokratisering med införande av religionsfrihet och utbyggnad av välfärdsstat, globalisering, migration och ett förändrat mediesamhälle - har ju också bidragit till en ökad diversifiering och mångfald eller fragmentisering om man så vill. Takten i diversifieringen har ökat och blivit mer synlig de senaste decennierna. Thalén (2018) menar att objektivitetskravet introducerades i dåvarande kristendomskunskapsämnet 1962 för att hantera mångfald, men då var det främst mångfalden av åsikter och livsåskådningar man hade $\mathrm{i}$ åtanke mot bakgrund av den då pågående kulturdebatten. 
När man idag talar om mångfald åsyftas oftast etnisk, språklig och kulturell mångfald. Sverige har idag en jämförelsevis hög andel utrikes födda - 2019 uppges $25,5 \%$ av befolkningen själva vara födda $i$ ett annat land eller ha två föräldrar som är födda utanför Sveriges gränser (SCB, 2019). Om man dessutom inkluderar personer som till exempel har en förälder, är gift med, har en svärson eller svärdotter, svärfar eller svärmor som är födda i ett annat land blir andelen personer som lever i «mång-etniska familjer» avsevärt högre. I denna bemärkelse är etnisk, kulturell och språklig mångfald ett deskriptivt faktum som givetvis även präglar skolan. Samtidigt är det svenska samhället och skolsystemet extremt segregerat (SOU, 2017). Det finns kommuner som till exempel Botkyrka och Haparanda som har ungefär $40 \%$ utrikes födda medan andra kommuner såsom Piteå och Öckerö har mindre än $7 \%$. Det finns skolor i många kommuner som har mindre än $5 \%$ utrikes födda samtidigt som andra skolor i samma kommun har över $90 \%$ utrikes födda (Skolverket, 2019). Samtidigt är gruppen utrikes födda på intet sätt en homogen grupp, lika lite som inrikes födda är det. Till exempel genus, klass, utbildningsbakgrund, ekonomi, yrke, stad-landsbygd liksom religionstillhörighet är sociala kategorier och identiteter som skär igenom grupperna inrikes/utrikes födda.

Olika identiteter och sociala kategorier kommer i förgrund i olika sammanhang. Tidigare har begreppet «mångkulturella skolor» ofta används för skolor med hög andel utrikes födda. Vissa av dessa skolor och klasser kan vara ganska homogena och till exempel ha en majoritet av elever med muslimsk bakgrund från ett specifikt land, de senare åren till exempel Syrien eller Somalia. På samma sätt som klassrum där en majoritet identifierar sig med sekulära positioner påverkar klassrumssamtalet, påverkar majoritetsförhållanden i klassrummet om majoriteten identifierar sig med muslimska positioner samtalet som förs i det klassrummet. En stor och intressant skillnad blir dock att samtalen påverkas av man som troende minoritet förhåller sig till ett sekulärt majoritetssamhälle. Under klassrumsobservationer har jag noterat att uttryck som «vi» utelämnas när man pratar om Sverige - i stället för att tala om «vi i Sverige anser/tror/gör etc» används uttrycket «i Sverige anser /tror /gör [man]» trots att de flesta elever är födda i Sverige eller kommit till Sverige som riktigt små. Och att i dessa klassrum artikulera ateistiska positioner är sannolikt lika svårt som att artikulera religiösa positioner i ett klassrum där troende är i minoritet.

Jag har i olika forskningsprojekt genomfört ett stort antal klassrumsobservationer i religionskunskap. Jag menar att det är tydligt att elevernas bakgrunder, identiteter och åsikter och hur majoritetsförhållandena ser ut i det specifika klassrummet har betydelse för hur man talar och vad som blir möjligt att lära. Nilsson (2018) använder uttrycket det «ogeneraliserbara och oförutsägbara klassrummet» för att beskriva mångfalden av erfarenheter och identiteter som 
lärare i religionskunskap behöver förhålla sig till. Det innebär inte att lärare inte för in ny kunskap och nya perspektiv in i klassrummet, men diskussioner påverkas i hög grad av elevernas förståelse för det som diskuteras och de präglas av deras tidigare erfarenheter. Vid klassrumsobservationer är det tydligt att det finns en stark strävan efter konsensus i klassrummet och lärare arbetar i interaktion med elever.

\section{Mångfald som problem}

Då tolerans och öppenhet är värden som många i Sverige uppskattar och, som framkommit ovan, i många fall associeras med svenskhet, har den generella attityden till migration och mångfald varit positiv de senaste decennierna. Internationell solidaritet med människor i utsatta situationer som flyr från krig, förtryck och umbärande har varit ledord bland företrädare för partier från (nästan) hela den politiska skalan. De senaste åren har dock detta förändrats. Från «Refugees welcome», «Öppna era hjärtan» och «Mitt Europa bygger inte murar» (Eriksson \& Karlsson, 2014; Forsberg, Hagberg, \& Svensson, 2015; Järkstig, 2015) domineras nu talet om migration av uttryck såsom «mindre volymer», «ordning och reda», «språkkrav», «kontroll», «kaos», «problem» och politiker från alla politiska läger tävlar om att framstå som den mest ansvarsfulle som ställer störst krav och förespråkar den striktaste politiken. I denna diskurs som nu dominerar det offentliga samtalet framställs etnisk, kulturell och religiös mångfald som huvudsakligen problematisk, vilket också är belagt i undersökningar (Ahmadi \& Palm 2018). I inledningen av denna text nämndes dagsaktuella frågor såsom förbud för manlig omskärelse, konfessionella friskolor, bön på arbetstid och slöja i grundskolan. Ett sätt att förstå detta är att mångfald, här i form av religiösa praktiker, upplevs hota det sekulära samhället varför samhället behöver fredas för detta. Ett annat perspektiv är att dessa uttryck är ett sätt att skapa och markera tydligare gränser för ett «svenskt [sekulärt] vi» i relation till ett odefinierat «dom». Denna migrationskritiska diskurs förekommer inte bara i Sverige och politiska ledare över hela världen, till exempel i USA, Brasilien, Indien, Ungern og Turkiet, spelar på nationalistiska och populistiska stämningar.

Detta skifte är synligt i klassrummen. Å ena sidan upplever de flesta elever mångfald som positiv och tämligen oproblematisk i sin vardag (Vikdahl, 2018). Samtidigt är det min bild i de observationer jag genomfört samt samtal med verksamma lärare att migrationskritiska åsikter med varierande grad av underliggande främlingsfientlighet yttras oftare nu. I intervjuer jag genomfört beskriver lärare att när de i klassrummet nu tar upp läroplanens (Skolverket, 2011a) värderingar som till exempel alla människors lika värde, solidaritet mellan människor, generositet, tolerans och ansvarstagande, uppfattas de som ickeneutrala och att de förespråkar «vänster-åsikter». Hela den politiska skalan tycks 
ha förflyttats högerut. Detta medför att dessa värderingar, som när denna del av läroplanen skrevs i början av 1990-talet uppfattades som centrala värderingar i mitten och som alla politiska partier enades om då, nu uppfattas som partiska med slagsida åt en politisk vänster.

\section{SKÄRNINGSPUNKTER MELLAN SEKULARITET OCH MÅNGFALD}

Hur hanteras då balansakten mellan det sekulära och olika aspekter av mångfald i religionskunskapsklassrummen? Som redan har berörts så är det svårt att beskriva hur det ser ut «i svensk skola», för det är på så många sätt samtidigt. Elevernas erfarenheter och åsikter i den specifika klassen påverkar hur innehållet tas emot. Det flera lärare lyfter som svårt är att de inte vet hur ett specifikt innehåll ska tas emot. Ibland anar de att en viss fråga kan uppfattas som kontroversiell i en viss klass och organiserar undervisningen med denna beredskap. Men ibland väcker frågor som lärarna trodde skulle vara helt oproblematiska enormt starka känslor. Det kan till exempel handla om frågor relaterade till migration, terrorism, antisemitism, Israel-Palestinafrågan, yttrandefrihet och olika tolkningar och förhållningssätt till religiösa urkunder (K Flensner 2019; 2020). Detta upplever många lärare som jobbigt, dels för att de inte har kontroll i klassrummet men också för att andra elever kan bli utsatta $\mathrm{i}$ den typen av diskussioner (jmf K. Flensner \& Von der Lippe, 2019; Jannert \& Persson, 2018). Orsaker till dessa emotionellt polariserade diskussioner är ibland rena missförstånd, språkförbistring eller brist på kunskap. Här behövs medvetna strategier och metoder för att arbeta med frågor som uppfattas som kontroversiella (se t.ex. Hess, 2009) för att skapa den dialog och förståelse undervisning syftar till.

Om objektivitetskravet infördes i dåvarande kristendomskunskapsämnet för att, utifrån en neutral ståndpunkt, hantera en ökad mångfald av åsikter, används idag många gånger ett sekularistiskt förhållningssätt till religion i religionskunskapsundervisningen för att hantera religiös och kulturell mångfald. Orsaken till detta hänger ofta samman med ambitionen att förmedla en neutral, objektiv och opartisk bild av religion som inte är konfessionell. Vid användande av denna ansats behöver man förhålla sig reflexiv över sina egna förgivettaganden. Risken finns annars att man bidrar till andrafiering av troende elever och inte når mål som stipuleras i ämnesplanen för religionskunskap som handlar om förståelse och att förbereda eleverna för att leva i ett samhälle som präglas av mångfald (Skolverket, 2011b). Sekularistiska och ateistiska ståndpunkter är helt legitima positioner, men de är inte neutrala utan behöver synliggöras och problematiseras liksom andra utgångspunkter.

I projektet Global conflicts with local consequences - learning and arguing about Middle Eastern conflicts in Swedish classrooms har vi analyserat lärares strategier för att hantera kontroversiella frågor. Resultaten från denna studie 
indikerar att lärare många gånger undviker kontroversiella frågor genom att avbryta elever eller inte fånga upp deras kommentarer, tona ner olikheter i åsikter och därigenom undvika att ett område eller fråga diskuterades. Andra strategier handlade om att just synliggöra olika åsikter och positioner eller att arbeta med teater och film för att träna eleverna $i$ att byta perspektiv och på så sätt främja empati och förståelse. Detta kan förstås som en skillnad i att hantera kontroversiella frågor eller att undervisa $i$ och om kontroversiella frågor. Sekularitet och mångfald är områden där det finns starka åsikter i samhället och så också i många klassrum och detta är tematiker som personligen berör många elever. En stat kan vara sekulär, men ett samhälle kan aldrig vara sekulärt då det befolkas av människor med alla möjliga livsåskådningar. Ett sätt att se skolans och speciellt religionskunskapsämnets utveckling är en pendling mellan att hantera och bekräfta olika aspekter av mångfald och att ha en enhetsskapande funktion. $\AA ̊$ ena sidan ska utbildningsväsendet främja tolerans, respekt och generositet. Samtidigt måste all utbildning förhålla sig till frågor som rör hur individer och grupper med olika intressen och tillhörigheter kan leva tillsammans så att elever upplever att de samtidigt får vara ett unikt «jag» och del av ett mångfacetterat «vi» (jmf K. Flensner, 2018a; Touraine \& Öberg Lindsten, 2003).

\section{LITTERATUR}

Ahmadi, F., \& Palm , I. (2018). Mångfaldsbarometern 2018 Hentet fra https:// www.hig.se/download/18.321e5b271641cca84643f3ba/1534110403023/ M\%C3\%A5ngfaldsbarometern_2018.pdf

Almén, E. (2000). «Religious Education in Sweden.» I E. Almén \& H. C. Øster (red.), Religious education in Great Britain, Sweden and Russia. Presentations, problem inventories and commentaries. Texts from the PETER project. Linköping: Linköping University Electronic Press.

Berger, P. (1967). The sacred Canopy. Garden City, NY: Anchor books

Berglund, J. (2017). «Secular normativity and the religification of Muslims in Swedish public schooling.» Oxford Review of Education, 43(5), 524-535. doi:10 .1080/03054985.2017.1352349

von Brömssen, K. (2009). «Time and 'the Other/s', Scientism, and GenderStatements. Discourses on Religion in a Swedish 'Multi-Cultural' School.» I L. Roos \& B. Jenny (red.), Your Heritage and Mine. Teaching in a Multi-Religious Classroom (s. 94-106). Uppsala: Studies in Inter-Religious Relations 43.

von Brömssen, K. (2012). «Elevers möten med religion i gymnasieskolan.» I M. Lövheim \& J. Bromander (red.), Religion som resurs? Existentiella frägor och värderingar i unga svenskars liv (s. 131-155). Skellefteå: Artos. 
von Brömssen, K. (2016). «Some ethnic Swedish students' discourses on religion. Secularism par excellence.» Journal of Religious Education(2), 113. doi:10.1007/ s40839-017-0036-6

Carlsson, D., \& Thalén, P. (2015). Det postsekulära klassrummet. Mot ett vidgat religionskunskapsbegrepp. Uppsala: Swedish Science Press.

Cassanova, J. (2003). «Beyond European and American exceptionalism. Towards a global perspective.» I G. Davie, P. Heelas, \& L. Woodhead (red.), Predicting religion. Christian, secular, and alternative futures. Aldershot: Ashgate.

Dobbelaire, K. (2009). «The Meaning and Scope of Secularization.» I P. B. Clarke (red.), The Oxford handbook of the sociology of religion. Oxford: Oxford University Press.

Durkheim, E. (1976 [1912]). The elementary forms of the Religious Life. London: Allen \& Unwin.

Eddebo, J., Ewert, P., \& Magnusson, S. (2020). Kränkt för sin tro. Kristna ungdomars upplevelser av sekulär intolerans $i$ dagens svenska skola. Hentet fra http://www. claphaminstitutet.se/wp-content/uploads/2020/09/Clap-Rapport4_helpdfhemsida.pdf

Eriksson, N., \& Karlsson, P. (2014, 16 augusti 2014). Fredrik Reinfeldt: «Öppna era hjärtan.» Aftonbladet.

Flensner, K. K. (2015). Religious education in contemporary pluralistic Sweden. Göteborg: Department of Literature, History of Ideas, and Religion, University of Gothenburg.

Flensner, K. K. (2018a). «Secularized and Multi-Religious Classroom PracticeDiscourses and Interactions.» Education Sciences, Vol 8, Iss 3, p 116 (2018)(3), 20. doi:10.3390/educsci8030116

Flensner, K. K. (2018b). «Existential questions in Religious Education. Opening up discussions in upper secondary school.» I J. Ristiniemi, G. Skeie, \& K. Sporre (red.), Challenging Life. Existential Questions as a Resource for Education. (s. 397-415). Münster: Waxmann.

Flensner, K. K., (2019). «Samma konflikter men olika inramning. Kontroversiella frågor relaterade till Mellanösternkonflikterna i religionskunskap och samhällskunskap.» Nordidactica - Journal of Humanities and Social Science Education. 2019(3) s 73-100.

Flensner, K. K. (2020) «Teaching Controversial Issues in Diverse Religious Education Classrooms.» Religions. 11(9):465, s 1-25. doi.org/10.3390/ rel11090465

Flensner, K. K., \& Von der Lippe, M. (2019). «Being safe from what and safe for whom? A critical discussion of the conceptual metaphor of 'safe space'.» Intercultural Education, 1-14. doi:10.1080/14675986.2019.1540102

Flensner K., K., Larsson, G., \& Säljö, R. (2019). «Jihadists and Refugees at 
the Theatre. Global Conflicts in Classroom Practices in Sweden.» Education Sciences, 9(2). doi:10.3390/educsci9020080

Forsberg, O., Hagberg, S., \& Svensson, O. (2015, 6 September). «Mitt Europa bygger inte murar, vi hjälps åt» [My Europe build no walls, we help each other]. Aftonbladet.

Hess, D. E. (2009). Controversy in the classroom. The democratic power of discussion.

Holmqvist Lidh, C. (2016). Representera och bli representerad. Elever med religiös positionering talar om skolans religionskunskapsundervisning. Karlstad: Karlstads universitet.

Jannert, H., \& Persson, C. (2018). «Interkultulturell religionsundervisning i praktiken» [Intercultural Religious Education teaching in practice]. I O. Franck \& P. Thalén (red.), Interkulturell religionsdidaktik. Utmaningar och möjligheter [Intercultural pedagogic of Religious Education. Challenges and oppurtunities]. Lund: Studentlitteratur.

Järkstig, L. (2015, 8 september 2015). «Många visade kärlek när flyktingarna kom.» Aftonbladet.

Luckmann, T. (1967). The invisible religion. The problem of religion in modern society. New York: Macmillan.

Moulin, D. (2011). "Giving voice to 'the silent minority'. The experience of religious students in secondary school religious education lessons.» British Journal of Religious Education, 33(3), 313-326. doi:10.1080/01416200.2011.5 95916

Nilsson, S. (2018). «Det oförutsägbara klassrummet. Utmaningar och möjligheter» [The unpredictable classroom. Challenges and opportunities]. I O. Franck \& P. Thalén (red.), Interkulturell religionsdidaktik. Utmaningar och möjligheter [Intercultural pedagogic of Religious Education. pChallenges and oppurtunities]. Lund: Studentlitteratur.

Osbeck, C., \& Lied, S. (2011). «Hegemonic speech genres of classrooms and their importance for RE learning.» British Journal of Religious Education, 34(2), 155-168. doi:10.1080/01416200.2011.628194

SCB. (2019). Befolkningsstatistik i sammandrag 1960-2019. https://www.scb. se/hitta-statistik/statistik-efter-amne/befolkning/befolkningens-sammansattning/befolkningsstatistik/pong/tabell-och-diagram/helarsstatistik--riket/ befolkningsstatistik-i-sammandrag/

Scharffs, B. G. (2011). «Four views of the citadel. The consequential distinction between secularity and secularism.» Religion \& Human Rights, 6(2), 109-126.

Skolverket. (2011a). Läroplan, examensmål och gymnasiegemensamma ämnen för gymnasieskola 2011, Lgy 11. Stockholm: [The Swedish National Agency for Education]. 
Skolverket. (2011b). Ämnesplan Religionskunskap. Stockholm Hentet fra http:// www.skolverket.se/content/1/c6/02/39/50/Gymgemensamma.pdf.

Skolverket. (2019). Statistik. Skolverket. https://www.skolverket.se/skolutveckling/statistik/sok-statistik-om-forskola-skola-och-vuxenutbildning?sok=SokA SKR. (2020). "Rapport. Unga troende $i$ samhället. Varannan kristen ungdom upplever sig kränkt för sin tro.» Hentet fra https://www.skr.org/wp-content/ uploads/2020/02/unga-troende-i-samhallet-16-sidor-den-29-april-2020.pdf:

SOU. (2017). Samling för skolan. Nationell strategi för kunskap och likvärdighet. Slutbetänkande [Together for school. National strategy for knowledge and equivalence. Final report]. (978-91-38-24601-6). Stockholm: Wolters Kluwer Hentet fra http://www.regeringen.se/rattsdokument/statens-offentliga-utredningar /2017/04/sou-201735.

Taylor, C. (2007). A secular age. Cambridge, Mass.: Belknap Press of Harvard University Press.

Thalén, P. (2018). «Att vara religionslärare i en tid av radikal mångfald» [To be a teacher of Religious Education in times of radical plurality]. I O. Franck \& P. Thalén (red.), Interkulturell religionsdidaktik. Utmaningar och möjligheter [Intercultural pedagogic of Religious Education. Challenges and oppurtunities]. Lund: Studentlitteratur.

Thurfjell, D. (2015). Det gudlösa folket. De postkristna svenskarna och religionen. Stockholm: Molin \& Sorgenfrei.

Touraine, A., \& Öberg Lindsten, K. (2003). Kan vi leva tillsammans? Jämlika och olika. Göteborg: Daidalos.

Weber, M. (2003 [1958]). The Protestant ethic and the spirit of capitalism. Mineola, N.Y.: Dover Publications.

Vikdahl, L. (2018). Det kommer inte på tal. En studie om religiös och kulturell mångfald i grundskolan. Skellefteå: Artos Academic.

Willaime, J.-P. (2007). «Different models for Religion and Education in Europe.» I R. Jackson, S. Miedema, W. Weiße, \& J.-P. Willaime (red.), Religion and education in Europe. Developments, contexts and debates (Vol. 3). Münster: Waxmann. 